\title{
SARAJEVON DERVISSIEN SAKRAALI LAULANTA
}

Islamilaisten mystikkojen sakraali laulanta on saanut viime vuosina julkisuutta islamilaisen maailman ohella myös Länsi-Euroopassa. Suomessa pakistanilaiset ja turkkilaiset sufi-muusikot ja tanssijat ovat esiintyneet ainakin Helsingissä, Seinäjoella ja Kuopiossa. Harva tulee kuitenkaan ajatelleeksi, että sufi-veljeskuntia on ollut vanhastaan myös Euroopassa - nimittäin Balkanilla. Sarajevo ja Priština Jugoslaviassa ovat nyky-Balkanin sufismin tärkeimmät keskukset.

Tämä artikkeli perustuu vuoden 1988 alussa Sarajevossa tekemääni kenttätyöhön ja sen pohjalta kirjoittamaani tutkielmaan (ks. Pennanen 1990a). Aluksi esittelen Sarajevon dervisseille ominaiset sakraalin laulannan lajit ja niiden käyttöyhteydet. Oikeaoppisille moskeijarituaaleille ja sufilaisille rituaaleille yhteiset laulantalajit - esimerkiksi koraaniresitaatio ja rukouskutsu - rajautuvat siis tarkastelun ulkopuolelle. Tämän jälkeen esittelen ja analysoin sarajevolaisen, puolivälissä kuuttakymmentä olevan kemianopettaja Seid Strikin musiikkikäsityksiä.

Sarajevon dervissit pitävät nakšibendija -mystikkoveljeskuntaan kuuluvaa Strikiä asiantuntijana, koska tämä on koonnut tietoa islamilaisesta laulannasta ja saattanut käsityksensä kirjalliseen muotoon. Strikin musiikillinen maailmankuva piirtyy näkyviin haastattelumateriaalin, hänen Šebi-arus -vuosikirjassa julkaisemansa artikkelin sekä julkaisemat- 
toman käsikirjoituksen kautta (ks. Y 9749; Y 9750; Strik 1987; ibid. 1988).

\section{Islamilainen tausta}

Bosnian muslimit ovat islaminuskoisia, jotka puhuvat äidinkielenään serbokroaattia. Itse he kutsuvat itseään pelkästään muslimeiksi (muslimani). Jugoslavian väestönlaskennassa heidät luokitellaan muslimeiksi kansallisuutena (muslimani u smislu narodnosti). 86 \% serbokroaatinkielisistä muslimeista asuu Bosnia-Hertsegovinan osavaltiossa. Vuoden 1981 väestönlaskennassa Bosnia-Hertsegovinan asukkaista $39.52 \%$ ilmoitti olevansa kansallisuudeltaan muslimeja, $32.02 \%$ serbejä sekä $18.38 \%$ kroaatteja. Väestön loppuosa sanoi olevansa jugoslaaveja tai katsoi kuuluvansa muihin kansallisuuksiin. (Lockwood 1984, 172-173; Markotic 1983, 36).

Islaminuskon leviämisen huippukausi Bosniassa ylsi osmanivallan alkuajoilta 1460-luvulta 1600-luvulle. Bosnian käännynnäiset omaksuivat islamin sunnilaisen suuntauksen. Uskonnon doktriini ja käytäntö muistuttavat läheisesti turkkilaisia esikuviaan. Bosnian muslimikulttuurissa on muutenkin runsaasti turkkilaisia vaikutteita, jotka ovat muuntuneet usein omaperäisiksi paikallisvarianteiksi. (Filipović-Hadžidedić 1983, 122).

Turkkilaiskausi päättyi vuonna 1878, jolloin Itävalta-Unkari miehitti Bosnia-Hertsegovinan Berliinin kongressiin päätösten mukaisesti. Ensimmäisen maailmansodan jälkeen maakunnat kuuluivat Serbien, kroaattien ja sloveenien kuningaskuntaan, ja toisen maailmansodan jälkeen niistä tuli Jugoslavian sosialistisen liittotasavallan osavaltio.

\section{Sufismi ja samâ}

Triminghamin $(1971,1)$ mukaan sufilla tarkoitetaan muslimia, joka pyrkii saamaan suoran kokemuksen Jumalasta. Sufismi perustuu oikeaoppisen islamin tavoin uskonnollisen sharî́a-lain ja teologian täydentämään profeetalliseen ilmoitukseen. Islamilaiset lainoppineet ovat tästä huolimatta suhtautuneet sufismiin vihamielisesti, koska mystikot ovat väittäneet omaavansa tiedon Jumalasta. Sufien mielestä systematisoitu kirjauskonto ei anna tätä tietoa. 
Sufismi alkoi vaikuttaa Bosniassa ja Hertsegovinassa jo ennen näiden alueiden liittämistä osmanien valtakuntaan. Maakuntien oikeaoppiset islamilaiset viranomaiset ovat aina kontrolloineet veljeskuntien toimintaa. 1950- ja 1960-luvuilla sufilainen perinne pyrittiin tukahduttamaan sulkemalla tekija-kokoontumistilat, joista kolme on otettu uudelleen käyttöön 1970-luvun lopulta lähtien (ks. Cehajic 1986, 198-200; Hadžibajrić 1979). Toisen maailmansodan jälkeen Sarajevon veljeskuntien määräksi on vakiintunut neljä. Niistä kadirija, naksibendija ja mevlevija ovat sunnilaisia. 1980-luvulla kaupunkiin saapui צiialaisvaikutteinen rifaija.

Sufi-veljeskunnissa vallitsee jäsenistön tiukka hierarkia. Sarajevon Hadži-Sinanova -tekijan kalenterin mukaan kadirija-veljeskunnan jäsenistö jakaantuu seuraavasti: zikirin ja veljeskunnan johtamiseen valtuutettu Seikki (̌́jh), zikirin johtamiseen valtuutettu vekil, tekijan jäseniä auttava rehber, uskollisuusvalan vannonut dervissi (dervis") eli murid, rukouskaavan tunteva, mutta valaa vannomaton muhib sekä prijatelj tarikata 'veljeskunnan ystävä' eli simpatizer, joka ei tunne rukouskaavaa. (Kalendar).

Sufilaisen ajattelun mukaan tavallisen ihmisen tajunta on siirtynyt pois olemuksensa ytimestä, jonka juuret ovat Jumalassa. Se on vangittu uneen ja unohdukseen. Ihmistä täytyy "muistuttaa" unohtamastaan, minkä vuoksi sufit harjoittavat dhikr- eli zikr- tai zikir-rituaalia. Dhikr tarkoittaa 'muistelua', 'rukousta', 'mainitsemista' ja 'avunhuutoa'. Dhikrissä Jumalan nimiä ja epiteettejä toistetaan jatkuvasti joko ääneti tai ääneen rytmisesti hengittäen. Rituaali saattaa johtaa transsitilaan. Sufit käyttävät dhikriensä yhteydessä myös laulantaa, soittoa ja tanssia. (Burckhardt 1960, 114; Trimingham 1971, 194).

Yksi oikeaoppista islamia ja sufismia erottava piirre on suhtautuminen musiikin kuunteluun (samâ) uskonnollisissa yhteyksissä. Profeetta Muhammed suhtautui musiikkiin kielteisesti luultavasti välttääkseen pakanalliseen runouteen assosioitua laulua ja soittoa. Koraaniresitaation (qirâ'a 'lukeminen') tuli poiketa runouden laulamisesta, koska Muhammed halusi pitää kuulijoidensa ajatukset pois näiden aiemmasta uskonnosta. ${ }^{1}$ (Farmer 1957, 439).

Musiikkia vastustaneiden lainoppineiden mielestään laulaminen oli sopimatonta, joten he erottivat toisistaan äänenkorkeuden vaihteluun perustuvan sakraalin laulannan (taghbîr 'äänen korottaminen') ja profaanin

1) Lisää islamilaisesta musiikkikäsityksestä ks. Pennanen 1990b. 
laulamisen (ghinâ). Toisin kuin ammattimuusikoiden harjoittaman laulamisen, laulannan ei katsottu vaativan musiikin opintoja. (Ibid.). Oikeaoppisen islamin laulannan lajeja koraaniresitaation ohella ovat rukouskutsu sekä erilaiset hymnit.

Sufilaisessa käsityksessä samâ'sta on yleensä piirteitä sekä sitä vastustavien että musiikkia taiteena puolustavien näkökannoista. Mystikkoja ei kiinnostanut musiikki sen itsensä vuoksi. Toisaalta he kiistelivät myös kuuntelun laittomaksi julistaneiden kanssa. Mystikoiden mielestä kuuntelu voi liikuttaa sydäntä, mikä saattaa johtaa hengelliseen haltioitumiseen. (Robson 1938, 11).

Esimerkiksi sufismin teoreetikon Rûzbahân Baqlî Shîrâzîn (11281209) mukaan on olemassa kolmenlaista hengellistä musiikkia: tavallisille ihmisille, eliitille sekä eliitin parhaimmistolle tarkoitettua. Tavalliset ihmiset kuuntelevat epätäydellisen, intohimojen hallitseman luontonsa kautta. Eliitti kuuntelee sydämellä ja etsii Jumalaa. Eliitin parhaimmisto kuuntelee sielullaan, ja tällainen kuuntelu on Jumalan rakastamista. (Nasr 1976, 44).

Oikeaoppisen islamin laulannasta ja mystikkoveljeskuntien rituaalilaulannasta ja -soitosta puhuttaessa islamilaisessa kielenkäytössä ei hyväksytä profaaneihin yhteyksiiin varattua kreikkalaisperäistä sanaa mûsîq $\hat{\imath}$ tai sen johdannaisia (Neubauer 1980, 342). Muuta kieltä kuin arabiaa puhuvissa islamilaisissa kulttuureissa käytetään taghbîr-sanan sijasta omakielisiä ilmaisuja, kuten turkin okunmak 'lukeminen' tai serbokroaatin učenje 'opettaminen, oppiminen'. UČenje-sanan suomenkieliseksi vastineeksi käy hyvin 'opettaminen'.

\section{Laulannan lajeja}

Arabialaisella kulttuurialueella profeetta Muhammedia ja hänen perhettään ylistäviä lauluja kutsutaan nimellä madîh annabawî. Niiden leviäminen on ollut paljolti mystikkoveljeskuntien ja sufi-runoilijoiden ansiota. Madîh annabawî -laulujen alalajeja ovat tanzîla 'ilmestys', ibtihâl 'rukous', tawassul 'pyyntö' sekä tawsîh eli muwashshah. (Touma 1989, 198-199; 201). Qașî́da, ghazal ja qawwali ovat muita islamilaisten alueiden sakraalin laulannan lajeja. Sarajevossa ilahija on islamilaisen uskonnollisen laulun yleisnimi. Kasida on ilahijan tärkein alalaji, mutta $g a$ zelia pidetään omana laulantalajinaan. 


\section{Ilahija-laulut}

Sanalla ilâhi 'Jumalalle kuuluva, jumalallinen' tarkoitetaan erityisesti kaksi- tai neliosaisia sakraaleja taide- tai kansanlauluja, jotka liittyvät islamilaisen kalenterin tiettyihin kuukausiin tai juhlapäiviin. Turkissa ilâhi merkitsee turkinkielistä uskonnollista hymniä ja erityisesti sufilaista laulua. Arabiankielisistä ilâheista käytetään turkinkielistä nimitystä suğul. (Neubauer 1980, 343-344; Uzel 1990).

Bosnia-Hertsegovinassa ilahija-laulut ovat sakraaleja hymnejä, jotka on tarkoitettu esitettäviksi muualla kuin moskeijoissa. Osa niistä on arabialais- tai turkkilaisperäisiä. Bosniassa syntyneet ilahijat sisältävät vaikutteita paikallisesta kansanmusiikista. (Petrovic 1989, 131). Yleisin ilahijan määritelmä Sarajevon tekijoissa on pobožna pjesma 'uskonnollinen laulu, uskonnollinen runo'. Serbokroaatinkielinen sana pjesma tarkoittaa sekä 'laulua' että 'runoa'. Useimmat Sarajevossa haastatelluista zikireihin osallistujista nimittävät ilahijoiksi kaikkea tekijoissa 'opetettua' laulantaa lukuun ottamatta siitä selvästi eroavaa gazelia sekä sakraaleihin rituaaleihin suoraan liittyviä rukouskutsua, koraaniresitaatiota sekä tekbir- ja salavat-kaavoja.

Touman $(1989,199)$ mukaan Muhammedin kirjuri Hasan Ibn Thâbit runoili ensimmäisten madîh-laulujen tekstit heti profeetan kuoleman jälkeen vuonna 632. Ne toimivat myöhempien runojen esikuvina. Sen sijaan Seid Strik $(1987,149)$ pitää ilahijan edeltäjänä "Ešrekal-bedru" laulua, jossa ylistetään Muhammedin saapumista Medinaan. Nähtävästi Strik tarkoittaa tunnettua "Tala'a al-badru" -nimistä laulua.

Seid Strik kertoo, että joitain ilahija-runoja on käännetty monille kielille, ja että niiden sävelasu on sama kaikkialla islamilaisessa maailmassa. Näitä ovat "Ešrekal-bedru", "Kaside-i burda" sekä "Eshubhubeda". (Strik 1987, 149). Nezih Uzelin (1990) mukaan Strikin mainitsemat runot tunnetaan kyllä käännöksinä kaikilla muslimialueilla, mutta niiden sävelasut poikkeavat toisistaan huomattavasti. Esimerkiksi sufirunoilija al-Buşî̂în (k.1298) kirjoittama 182-säkeinen madịh-runouden mestariteos "Al-burda" eli "Päällysviitan oodi" on käännetty useimmille muslimien puhumille kielille sen sisältämän voimakkaan siunauksen vuoksi (Touma 1989, 200).

Strikin mukaan Sarajevon tekijoissa suosituimmat ilahijat ovat Selim Samin tekemiä, kun taas Hadži-Sinanova -tekijaa johtavan seikki Fejzulah Hadžibajrićin ilahijat ovat ajankohtaisimpia. Strik katsoo anatolialaisen yli tuhat ilahijaa kirjoittaneen Yunus Emren (k.1321) olleen 
kaikkein tärkein ja tuotteliain ilahijan laatija. Muita tärkeitä runoilijoita ovat olleet seikki Bironi sekä takentilainen Ali Sirnavi. (Y 9749). Strik tarkoittaa Bironilla arabialaista tiedemiestä Abû ar-Rayhân Mụ̣ammad ibn Ahmad al-Bîrûnîa (973-1048) ja Ali Sirnavilla 'Ali Shir Navâ'îta (1441-1501).

Useimmiten ilahijat tunnetaan alkusanojensa mukaan. Viimeinen säkeistö eli צahbejt ilmaisee runon kirjoittajan. Silti on olemassa ilahijoita, joiden laatijaa ei tunneta. Strik arvelee kirjoittajan olleen vaatimaton tai nimen jääneen vahingossa kopioimatta lauluvihkoon. Hän lisää, että pahansuopien veljeskuntien jäsenet voivat jättää sahbejtin tarkoituksella pois. Strik ei kerro, mitä veljeskuntia hän tarkoittaa. (Strik 1987, 150).

Strik luokittelee ilahijat käyttöyhteyden ja tekstisisällön perusteella. On olemassa ramazan-paastokuukauteen sekä bajram- ja mevlud-juhliin liittyviä ilahijoita. Jotkut ilahijat sisältävät rukouksen, joten niitä kutsutaan nimellä munadžati-dova. Mersijat ovat muslimin kuoltua esitettyjä valituslauluja. Nat tarkoittaa ylistyslaulua. Rubaija- ja katrem- luokkien täsmällinen merkitys ei ole selvä. Turkiksi rubaiyat on 'kokoelma nelisäkeitä' (< pers. rubâ'i 'nelisäkeinen runomitta'). Suurin osa ilahijoista on opettavia ja neuvovia nasihateja (< turk. nasihat < arab. naṣ̣̂ha 'neuvo, kehotus'). Strik toteaa, että eri ilahija-tyyppien erottamiseen toisistaan tarvitaan vain harvojen laulantaspesialistien omaamaa erityistietoutta (Strik 1987, 151).

\section{Kasida ilahija}

Qașîda eli kasida on esi-islamilaiselta ajalta peräisin oleva arabialaisen runouden laji. Klassinen qaṣîda on rakenteeltaan mutkikas oodi, jossa on 60:sta sataan jatkuvasti samaa loppusointua hyödyntävää säettä. Jokainen puolisäekin päättyy samaan riimiin. Lähes kaikki runomitat ovat sallittuja. Viimeisessä osassa runoilija mainitsee oman nimensä ja osoittaa kiitollisuutensa heimolleen tai mesenaatilleen. Runon aihe voi olla niin sakraali kuin profaani. Musiikillinen qaṣ̂ida-esitys ei perustu samana pysyvään rytmikaavaan. Kertosäe ja improvisoidut juoksutukset vuorottelevat, joten musiikillinen muoto on syklinen. Sakraali qaṣîda on levinnyt sufi-veljeskuntien välityksellä. Profaani qaṣîda saavutti taiteellisen huippunsa Egyptissä viime vuosisadalla. (Anonym 1989, 352; Touma 1989, 132).

Škaljić $(1985,399)$ määrittelee Bosniassa tunnetun kasidan pitkäksi 


\section{Pennanen}

arabian-, turkin- tai persiankieliseksi ylistysrunoksi tai -lauluksi, joka on riimitetty yhden loppusoinnun avulla. Hänen mukaansa kasidassa on vähimmillään 15 ja enimmillään yli sata säettä.

Sarajevon tekijoissa käyvät eivät ole yksimielisiä kasida-käsitteen sisällöstä. Strikin mielestä kasida on Muhammedia ylistävä ilahija, jonka sävelmä on duurissa. Samalla kasida on Strikille myös mekam eli melodiatyyppi. Suosituin ilahija Sarajevossa on kasida "Ešek kao bedrolina". (Y 9749; Strik 1987, 151).

\section{Gazel-laulut}

Laajalle alueelle levinnyt ghazal eli gazel oli alkuaan arabialainen 600luvulla kehittynyt runolaji. Ghazalin merkitys jäi vähäiseksi arabiankielisessä kirjallisuudessa, mutta 1200-luvulta alkaen siitä tuli persialaisen runouden tärkein laji. Sadi (k. 1292) ja Hafiz (k. 1390) kirjoittivat ihailluimmat persiankieliset ghazalit. Runolaji levisi persian kielen vaikutusalueille Anatoliaan sekä Keski- ja Etelä-Aasiaan. (Manuel 1989, 94).

Ghazal koostuu vaihtelevasta määrästä loppusoinnullisia säepareja, jotka on laadittu prosodisen mitan tarkkoja sääntöjä noudattaen. Loppusoinnut noudattavat kaavaa aa, ba, ca, da. A-säkeet päättyvät vaikeasti toteutettavaan kaksitavuiseen loppusointuun, joka luo runolle musiikillista luonnetta. Ghazalien teemat voivat käsitellä sufismia, filosofiaa, hulluutta sekä varsinkin onnetonta rakkautta. Mittansa, hienostuneen ja koristeellisen ilmaisutapansa sekä kertosäkeenomaisten loppusointujensa vuoksi nämä runot sopivat hyvin musiikin yhteyteen. (Ibid., 94-95).

Musiikinlajina ghazal on saanut monenlaisia ilmentymiä. Iranissa se muodostaa klassisen âvâz-laulun perustan, ja Pohjois-Intiassa sekä Pakistanissa tällä nimellä kutsutaan puoliklassista perinnelajia, sufilaista qawwali-laulantaa sekä populaarimusiikin lajia. (Ibid., 95).

Turkkilainen neliosainen gazel- eli ghazele-vokaali-improvisaatio voi perustua yhteen tai useampaan makam-sävellyssäännöstöön. Ensimmäisen osan nimi on zemin eli giriş ja siinä laulu aloitetaan valittua makamia toteuttaen. Sitä seuraavan nakarat-kertosäkeen päätteeksi melodia johdetaan makamin finalikseen. Tämän näennäislopetuksen jälkeen on vuorossa meyan-osa, jossa makam vaihdetaan toiseksi tai aiempaa makamia käsitellään toisessa oktaavissa. Gazel päättyy nakarat-osan kertaukseen. Toisen osan toistuminen vastaa rakenteellisesti ghazal-runon loppusointukaavaa. (Reinhard-Reinhard 1984, 96). 
Mikäli gazelin alle soitetaan rytmitausta, vapaametrinen, runsaasti koristeltu lauluosa etenee itsenäisesti siitä riippumatta. Yleisin tausta on hidas vatsatanssi- eli çiftetelli-rytmi:

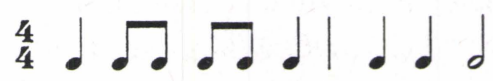

Gazel voidaan laulaa joko soitinsäestyksen kera tai sitä ilman. Soitinsäesteisen gazelin neljän itsenäisen osan välillä on välisoittoja (köprü 'silta'). (Ibid., 96-97). Kreikkalaisessa smyrneiko-musiikissa gazel-improvisaatiota kutsutaan nimellä manés tai amanés. Nämä nimitykset johtuvat sanasta amán, jota toistaessaan laulaja voi valmistella seuraavaa säettä. ${ }^{2}$

Seid Strikin mielestä gazel on melodialtaan oopperaa muistuttava ilahija, joka esitetään korkealla äänellä. Myös simpatizer Sakif määrittelee gazelin "oopperaksi, komediaksi". (Y 9749; Y9740).

Sarajevon tekijoissa esitettyjä gazeleita voi luonnehtia melodialtaan ja joskus tekstiltäänkin improvisoiduiksi lauluiksi, jotka esitetään ylärekisterissä. Gazelien melodiat ovat vapaametrisiä, ja ne voidaan esittää joko zikiriin kuuluvan, Jumalan epiteettien toistelusta koostuvan esmaosan hengityksen antamaa rytmitaustaa vasten tai zikirin jälkeen ilman rytmitaustaa. Gazelit kuuluvat Bosnian muslimien musiikkikulttuurin ravna pjesma -lajiin. Ravna pjesma 'tasainen laulu' tarkoittaa sitä, ettei musiikillinen metriikka rajoita laulajan ilmaisuvapautta. Laulajan odotetaan hallitsevan virtuoosisen koristelutaidon. ${ }^{3}$ (Petrovic 1989, 129).

Zikirin aikana gazelin teksti on sakraali, mutta muulloin se saattaa olla profaani. Tekijoissa usein 'opettava' Ferhad-pašsa Vuković-Desisalić -moskeijan mujezin eli rukouskutsun 'opettaja' Ganija Zagora käytti kadirija-veljeskunnan erään zikirin aikana esittämänsä gazelin sanoina Muhammedia siunaavaa salât-kaavaa. Sen sijaan dervissi Hoši-Gani esitti kerran naksibendija-veljeskunnan zikirin jälkeen gazelina turkinkielisen kehtolaulun, jota on laulettu alun perin Dardanellien taisteluissa ensimmäisen maailmansodan aikana isänsä menettäneille lapsille (ks. Y 9740; Y 9747; Erguner 1990).

2) Levy Amanédhes sisältää Turkista kotoisin olleiden kreikkalaisten pakolaismuusikoiden Kreikassa 1920- ja 1930-luvuilla levyttämiä amanéseja.

3) Rithman (1951, 36) vertaa ravna pjesmaa gregoriaanisen kirkkolaulun cantus planus -lajiin. 


\section{Pennanen}

Sarajevon tekijoissa käyvät sanovat gazelin vaativan erityistä lauluteknistä taitoa. Oman ilmoituksensa mukaan Seid Strik ei pysty esittämään gazelia. Vain Ganija Zagoran ja Hoß̌i-Ganin arvellaan taitavan gazelia. (Y 9749). Sitä esittäessään sekä Ganija Zagora että Hosi-Gani istuvat jalat ristissä. He pitävät oikeaa kättään korvalla ja näyttävät pinnistelevän saadakseen äänensä kuuluviin. Säkeiden välillä heidän on tapana laskea päänsä alas.

\section{Ilahijoiden esityskäytäntö Sarajevossa}

Ilahijat kuuluvat jokaiseen tekke-huoneistossa vietettyyn rituaaliin. Niitä voidaan 'opettaa' zikirin esma-osan aikana, jolloin esittäjiä on yleensä yhdestä kolmeen. Hidasta, kaikkien 'opettamaa' ilahijaa voidaan käyttää rauhoittamaan liian syvään transsitilaan joutuneita osanottajia. Kadirijazikirissä läsnäolijat esittävät yhdessä ilahijan lisäksi heti esme-osan jälkeen.

Nuottiesimerkki 1. Kadirija-veljeskunnan zikir-rituaalin esme-osan jälkeen kaikkien osanottajien 'opettama' nasihat-ilahija "Na srcu si bolestan" (Y 9734).

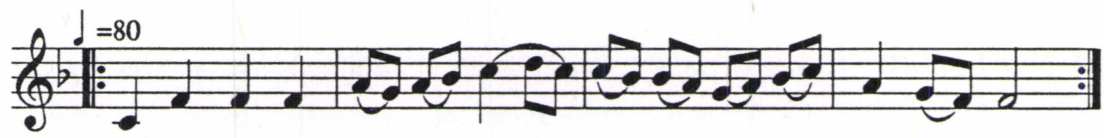

$\mathrm{Na}$ sr - cu si bo - les - tan

li - jek - ti si po - tre - ban.

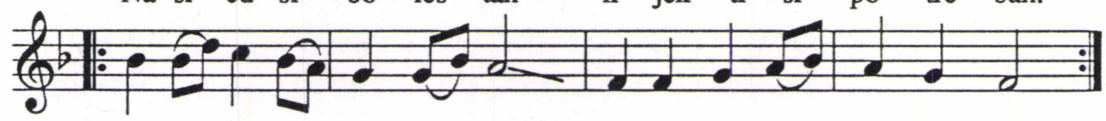

Do - dji u-dji u o- vaj, Dra-gog Rab-ba dju-lis - tan.

Zikiriä seuraa pyhien tekstien kääntämistä ja kommentointia. Sen jälkeisen teenjuonnin ja seurustelun aikana saatetaan 'opettaa' monta ilahijaa. Zikir-ilta päättyy lopulta ilahijaan, jonka kaikki osanottajat 'opettavat' piirissä seisten.

Ilahijoiden esitystapa Sarajevon tekijoissa on varsin heterofoninen, ja useimmat 'opettavat' alarekisterissä. Nasaalius ei ole hallitseva piirre. Kaupallisilla äänitteillä "Kur'an - ezan - salaat - ilahije" sekä "Ilahije i kaside" ilahijoita 'opetetaan' jatkuvasti ylärekisterissä erittäin nasaalisti. Kasettien kuoroesitykset eivät ole lainkaan heterofonisia. Äänitteillä esiintyy Sarajevon Gazi Husrevbegova medresa -oppilaitoksen oppilaita. 
Erään nakšibendija-zikirin jälkeen Hosi-Gani esitti kasidan, jonka kertosäkeeseen muut läsnäolijat yhtyivät. Äkkiä Hoši-Gani alkoi laulaa oktaavia muita ylempää. (Ks. Y 9740). Turkissa melodialinjan siirtymistä aiempaa ylempään oktaaviin nimitetään meyaniksi. Kudsi Ergunerin (1990) mukaan yläoktaaviin siirtyminen voi tapahtua spontaanisti.

Tekijoissa kaikkien 'opetettaviksi' tarkoitetut ilahijat ovat yleensä vähemmän melismaattisia kuin sooloina esitetyt. Itse asiassa joistain ilahijoista on olemassa kaksi versiota erilaisia esityskokoonpanoja varten. Strikin mukaan Şimu Zafer on säveltänyt alkuperäissävelmää kuorolle paremmin soveltuvan melodian Yunus Emren ilahijaan "Aşkun ile aşıklar". Strik kutsuu nimellä aksam (<*turk. aksam 'osat') ilahijaa, jonka runoilija ja säveltäjä ovat eri henkilö. Aksamin sävelmän laatija on oikea säveltäjä, joka luo taiteellisen melodian (umjetnicka melodija). (Y 9750).

Turkkilaisperäiset ilahijat 'opetetaan' Sarajevossa usein hitaammin kuin Istanbulissa. Sarajevossa tunnettujen turkkilais-ilâhien rytmiikka on saattanut muuttua; esimerkiksi bektaşi-veljeskunnan nefes-ilâhin "Ey çerhidun" 9/8-tahtilajia on vaikea tunnistaa fermaattien vuoksi (ks. nuottiesimerkki 2). ${ }^{4}$ Tempon hidastuminen ja rytmiikan muuttuminen johtunevat siitä, että Sarajevossa 'opettamista' ei juuri tueta soittimin. Lisäksi yhdistelmätahtilajit eivät ole yleisiä bosnialaisessa musiikissa.

Nuottiesimerkki 2. Seid Strikin 'opettama' bektaşi-veljeskunnan nefesilâhi "Ey çerhidun" (Y 9739).
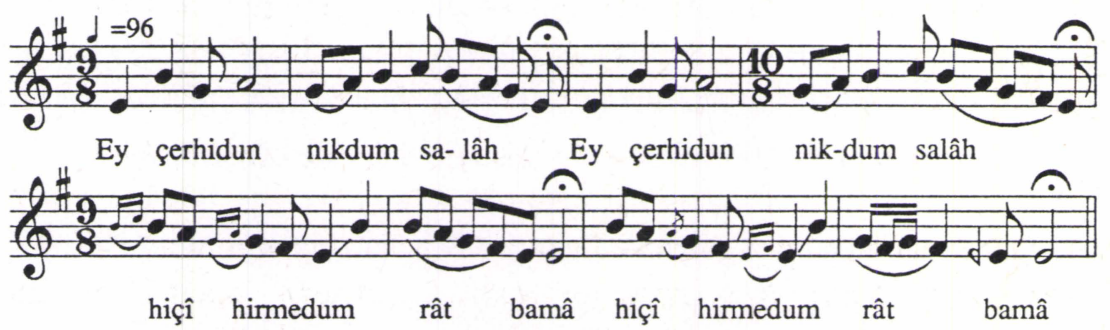

4) Turkista laajalle osmanien valtakunnan alueelle levinnyttä "Ey çerhidun" -sävelmää käytetään myös bosnilaisessa sevdalinka-rakkauslaulussa "Alija se do jezera krade". Turkista Kreikkaan muuttanut smyrneiko-säveltäjä Panajotis Toundas muunsi sävelmän tanssikappaleeksi. Tämä Roza Eskenazin vuonna 1936 levyttämä laulu "Dhimitroula" on julkaistu uudelleen levyllä Rembétiki istória 1925-55:1. 
Ilahijat 'opetetaan' tavallisessa zikirissä jalat ristissä istuen, kijam zikirissä seisten. 'Opettaja' voi käyttää tai olla käyttämättä lauluvihkoa eli medžmaa (< turk. mecmua 'kokoelma, monensisältöinen käsikirjoitus'), ja hän saattaa pitää oikeaa kättään sydämellä. Yleensä kuulijat tekevät kunnioitusta ilmaisevan sedždan kumartaen oikea käsi sydämellä ilahijan viimeisen säkeistön aikana, jolloin runon kirjoittajan nimi mainitaan. Zikirin jälkeisiin ilahijoihin voidaan reagoida tekemällä sedždan ja sanomalla Jumalan nimen $H \hat{u}$ 'Hän' laulannan päätyttyä. Myös 'opettaja' saattaa tehdä saman sanoen hiljaa "Muhammed resulullâh". Kuulijat voivat kommentoida hyvänä pitämäänsä esitystä joko normaalin serbokroaatin sanalla dobro 'hyvä' tai nimenomaan muslimien käyttämillä sanoilla ejvala 'kiitos, hyvä' (< turk. eyvallah < arab. îy wallâh) ja jasava (< *turk. yaşa 'eläköön').

Ilahijan sooloesityksissä ovat tärkeitä 'opettajan' äänenlaatu, laulannan sävelpuhtaus, etenkin selkeä ääntäminen sekä mahdollisesti vielä koristelutaito. Kaikkien läsnäolijoiden esittämissä yhteisilahijoissa nämä kriteerit menettävät merkitystään. Huonon ilahija-esityksen tunnusmerkit koetaan vaikeiksi verbalisoida. Tämä saattaa johtua ilahijan tekstin merkitystä korostavasta sakraalista luonteesta. Esityksen muut elementit jäävät toissijaisiksi.

\section{Seid Strikin musiikillinen maailmankuva}

Musiikillista maailmankuvaa voidaan tutkia kognitiivisen psykologian maailmankuvateorian avulla. Tällöin musiikillinen maailmankuva voidaan määritellä yksilön maailmankuvan hierarkkisen järjestelmän osarakenteeksi, hänen musiikkiin liittyvien käsitystensä kokonaisuudeksi. Musiikillinen maailmankuva heijastaa yksilön tärkeiksi kokemia elämänarvoja ja sisältää tulkittua tietoa todellisuudesta. Maailmankuva rakentuu yhtäältä arkielämän kokemuksiin pohjautuvista spontaaneista käsityksistä ja toisaalta lähinnä koulutuksen kautta välittyvistä ei-spontaaneista käsityksistä. (Karttunen 1990, 4-5). Yhteisön suhdetta musiikkiin yhtenäistävät musiikilliset peruskäsitykset ovat yhteisiä tietyn kulttuurin jäsenille. Yksilö muodostaa kuitenkin myös omia spontaaneja musiikkikäsityksiään. (Koskoff 1982, 353-354). Seid Strikin tapaus tukee tätä näkemystä. 
Serbokroaatin kielen uと̌enje-sanan käyttö puhuttaessa islamilaisesta laulannasta perustuu siihen, että laulannan esittäjän ajatellaan opettavan islaminoppia kuulijoilleen. Sanan kaksoismerkityksen 'opettaa - opiskella' vuoksi esittäjän voidaan ajatella 'opettaessaan' sisäistävän uskonnon perusteita. Spaićin $(1989,47)$ mukaan uđenje koostuu neljästä 'opettamisen' lajista: paikoitellen musiikin elementtejä sisältävästä erityisen ylevästä kerronnasta, määrättyä sävelmää noudattavasta kerronnasta, laulavasta resitoinnista sekä varsinaisesta laulamisesta. Spaic ei ota laulantaa kuvatessaan huomioon islamilaista kielenkäyttöä.

Petrović $(1989,129)$ kirjoittaa: "They [the Muslims of Bosnia and Herzegovina] subdivide the 'Muslim' music into 'secular' and 'religious reading' - 'religious chant'. Both types of music ('reading' - čitanje, and 'chant' - pjevanje) are exlusively monodic..." Kuitenkaan kukaan kenttäperiodin aikana haastatelluista ei käyttänyt sanaa 'Citanje' puhuessaan sakraalista laulannasta. Spaićin tavoin Petrović käyttää käsitettä 'pjevanje', joka sopii vain harvojen Bosnian muslimien mielestä uskonnollisiin yhteyksiin.

Sarajevon tekijoissa käyvät eivät ole yksimielisiä sakraalin laulannan luonteesta. Laulantaan liitetään monenlaisia käsitteitä ja käsityksiä, joista jotkut poikkeavat oikeaoppisesta islamista.

Rifaija-dervissi Fahrudin Priganićin mielipiteissä tulee esille sufismille ominainen käsitys, jonka mukaan laululla ja soitolla ei ole arvoa sinänsä. Priganić ei pidä ilahijoita - ääntä ja runoutta - kovinkaan kiintoisina tai tutkimisen arvoisina. Hän korostaa runoutta tärkeämpiä uskonnollisia ihanteita:

"Du intereßierst für Stimme aber ich intereßiere mich Herz. Erlichkeit, Gütigkeit. Ich liebe alle Leute. Wir sind alle Brüder und Schwestern. Wir haben einen Vater. Hazreti Aden und Eva. Das ist unsere Vater und Mutter. Keine Kriegen, keine Mörder. Keine Diebstahlen. Das ist wichtig. Erlichkeit ist wichtig. Das Lieben ist wichtig. Nein Stimme, nein Gedichte. ${ }^{5}$ (Y 9742).

Priganić sanoo Sarajevon rifaija-tekijassa olevan 'opettamista' ja uskonnollista runoutta (religiösische Gedichte), siis ilahijoita. Zikir on 'opettamista' ja tärkeää, perustavanlaatuista. Priganić ja hänen kanssaan

5) Informantti halusi puhua serbokroaatin sijasta saksaa. 
zikirin jälkeen keskustellut dervissi eivät olleet yksimielisiä ilahijan olemuksesta, sillä dervissi sanoi ilahijan olevan laulamista (pjevanje). Priganićin mielestä tekijassa voi olla musiikkia. Tällä hän tarkoittaa soitinten käyttöä. (Y 9742).

Simpatizer Sakib selittää 'opettamisen' liittyvän Koraaniin ja uskontoon. Ilahijan on kuin laulamista (kao pjevanje), mutta ucenje-sana on silti oikeampi. Siksi tekijassa ei lauleta, vaan ainoastaan 'opetetaan'. (Y 9739).

Erään Hadži-Sinanova -tekijassa käyvän simpatizerin kertoman mukaan toiset kutsuvat ilahijoiden esittämistä 'opettamiseksi' (uð̌enje), toiset laulamiseksi (pjevanje). UČenje on kuitenkin parempi käsite. Saman henkilön mielestä ilahijoita 'opetetaan' lähes aina ilman soitinsäestystä. Def-kehysrumpu on ainut sallittu instrumentti, ja sitä saa käyttää ainoastaan kijam zikirin aikana. Defin käyttäminen ei ole kuitenkaan soittoa (sviranje), vaan kuin rummuttamista (kao bubanje). Sen sijaan mevlevî-veljeskunnan tekijoissa Turkissa soitetaan, koska rituaaleissa esiintyy kokonainen orkesteri. (Y 9748). Sarajevossa ilahijoita säestetään ainoastaan lyömäsoittimin. Tämä tapahtuu kadirija-veljeskunnan seisaaltaan suoritetun kijam zikirin aikana.

\section{Strikin musiikkikäsityksiä}

Strikin mielestä ilahija on melodisoitu uskonnollinen runo (pjesma pobožna koja se melodiše). Se on laulamista (pjevanje). 'Opettamista' (učenje) ovat uskonnolliset rituaalit, kuten rukous, zikir-rituaali tai koraaniresitaatio. Strik erottaa laulamisen ja 'opettamisen' toisistaan siten, että laulamisen aikana on luvallista keskustella, tupakoida, syödä ja juoda teetä, 'opettamisen' aikana ei. Hän vertaa ilahijaa uskonnollisen koulun luentoon ja sanoo ilahijoiden esittämisen zikirin aikana olevan kauniiksi tekemistä (lijep\$avanje) sekä estetiikkaa (estetika). Niin ikään se on opetusta tai varoittamista (pouka). (Y 9749).

Strik kertoo joissain tekijoissa olevan myös soittoa (sviranje). Koska nakšibendija-veljeskunta on lähellä oikeaoppista sunnilaisuutta, sen tekijoissa ei soiteta. Tämän vuoksi nakšibendijalla ei ole musiikkia ( $m u$ zika). Kadirija, rifaija, halvetiye sekä erityisesti mevlevija sallivat soittamisen. Strikin mielestä halvetiye-veljeskunnan musiikki on melodisinta. (Ibid.).

Strik käyttää omaperäisesti sekä arabialais-turkkilaisen että länsi- 
maisen taidemusiikin käsitteitä. Hyvä esimerkki tästä on mekam. Signell määrittelee turkkilaisen makamin sävellyssäännöstöksi, jonka avulla luodaan musiikkikappaleen melodinen aines. Nykyisin Turkissa käytetään noin 70 makamia, joilla kullakin on oma nimensä ja mikrointervallirakenteensa. Makamia noudattavan melodian etenemistä määrää seyir-säännöstö, joka antaa säveltäjälle tai improvisoivalle muusikolle makamin tonaaliset keskustat. Lisäksi kullakin makamilla on määrätty melodinen suuntansa, joka voi olla nouseva, laskeva tai niiden välimuoto. (Signell 1977, 16; 48-50).

Bosnia-Hertsegovinan muslimien kielenkäytössä sanalla 'mekam' (< arab. maqâm 'paikka, asunto, viipyminen') on monta merkitystä. Se tarkoittaa Koraanin suuran tai rukouskutsun sopusointuista 'opettamista', melodiaa, säveltä, elämäntilannetta sekä tasoa sufismin henkisellä polulla. Petrovićin mukaan muslimit käyttävät profaaneista melodioista käsitettä kajde (< turk. kaide < arab. qâ'ida 'melodia') ja sakraaleista sävelmistä käsitettä mekam eli makam. Käsitteellä bosanski mekam he tarkoittavat paikallisia sakraalin laulannan melodioita, jotka poikkeavat Turkissa tai arabimaissa koulutettujen imaamien käyttämistä. (Skaljić 1985, 455; Petrović 1989, 135).

Strikille mekam on lähinnä sävelmätyyppi. Lähes kaikkien hänen mainitsemiensa mekamien nimet ovat peräisin turkkilaisesta musiikkiterminologiasta. Hän mainitsee nimet kasida, mersija, kalender, mehter, taksim, adžem aširan, sabah, ušak, akšam sekä dalmaca kingaca tepic. ${ }^{6}$ Joihinkin niistä hän liittää lisämääreitä: ilahijoissa yleinen kasida on duurissa, mersija mollissa, kalender iloinen ja boheeminen sekä mehter sotaisa. ${ }^{7}$ Taksim tarkoittaa osiin jaettua tai katkonaista 'opettamista'. Persialainen adžem aširan on huutava, kovaääninen. Aamuisen sabahrukouskutsun pitkään kestävän mekamin melodia on erityisen kaunis. Myös ušak liittyy sabah-kutsuun. Iltarukouksen akšam-mekam on nopea ja dalmaca kingaca tepic tietyllä tapaa boheeminen. (Y 9749; Y 9750).

Vaikka Strik mainitsee joidenkin turkkilaisten makam-sävellyssäännöstöjen nimiä, hän tietänee niistä vain vähän. Siitä huolimatta kaikki

6) Kalender turk. epätavallinen henkilö, boheemi, kiertävä kerjäläisdervissi; mehter < turk. mehterhane 'sotilassoittokunta'; taksim turk. 'jakaa osiin', 'vapaametrinen soitinimprovisaatio'; adžem aširan< turk. Acem 'Persia', asiran 'e-sävel'; turk. sabah 'aamu'. Sabâ [sic], uşşak ja acem-asiran ovat turkkilaisia makameja.

7) Strik sekoittaa toisiinsa sanat kalender ja kalenderî. Turkissa ja Iranissa kalenderî (< pers. qâlandarî) tarkoittaa saz-pitkäkaulaluutun säestyksellä 'opetettavaa' kansanomaista mystissävyistä runoa (ks. levy Iran 5 \& 6: Baloutchistan: 2B: 6). 
nimet keksityltä vaikuttavaa dalmaca kingaca tepiciä lukuun ottamatta liittyvät jollain tavoin musiikkiin tai laulantaan. Strik kuitenkin lisää mekamin käsitteeseen modaalisuudelle vieraan länsimaisen tonaalisen elementin, sävellajit.

On syytä olettaa, ettei mekamin käsite ole täysin selvä edes Strikin kaltaiselle spesialistille. Turkkilaisen korkeakulttuurin ammattimuusikoiden käyttämä mutkikas säveljärjestelmä on muuntunut ja yksinkertaistunut jouduttuaan suullisen perinteen piiriin ja taidemusiikkiin erikoistumattomien henkilöiden käyttöön. Turkkilaisen ja länsimaisen musiikinteorian elementtien rinnakkaisuus osoittaa Strikin spontaanien ja ei-spontaanien musiikkikäsitysten jääneen toisistaan irrallisiksi.

Strik käyttää länsimaisen taidemusiikin termistöä samalla tapaa kuin vastaavia turkkilaisia käsitteitä. Hän saattaa mainita yhtäällä gazelin olevan aina C-duurissa ja g-sävelessä ja toisaalla h-mollissa. Strik liittää ilahijoiden G- ja C-duuriasävellajiin määreen vedra 'iloinen' ja mersijoiden h-mollisävellajiin määreen tužna 'surullinen'. Tämä vastaa länsimaisessa taidemusiikista kansanomaiseksi levinnyttä duurin ja mollin luonnehdintaa, joka on ollut voimassa ainakin funktionaalisen harmonian kehittymisestä lähtien (Strik 1988, 4; ks. Cooke 1959, 50-54).

Strikin mielestä kaikki ilahijat eivät sovellu zikiriin rytminsä vuoksi. Rytmisesti sotilasmarssia muistuttavat ilahijat sopivat zikiriin parhaiten. Hän kutsuu tällaisia sävelmiä nimellä zikirski forte 'zikiriin liittyvä forte' (ks. nuottiesimerkki 3).

Nuottiesimerkki 3. Zikir-rituaalin esme-osan aikana 'opetettava' ilahija eli zikirski forte "Biri guluni" (Y 9740).

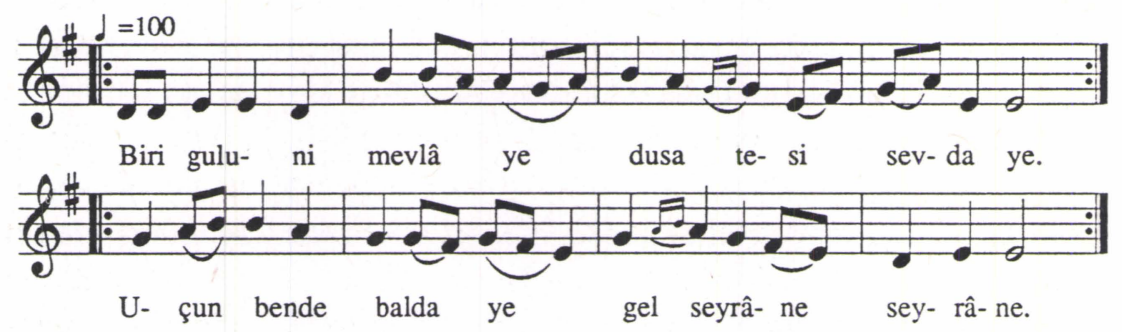

Gazelitkin sopivat zikiriin. Strik sanoo ilahijoiden yleisimmän tahtilajin olevan Jumalan epiteettien toistelun yhteyteen sopiva 4/4. Sen ohella ovat käytössä mevlevî-veljeskunnan suosima $8 / 8$ ja Strikin tahtilajeina pitämät C-duuria sekä G-duuri. (Y 9749). Länsimaisen perinteen näkökulmasta on yllättävää, että C- ja G-duuri ovat Strikille niin sävellajeja 
kuin tahtilajejakin (ks. Y 9749). Hän käyttää käsitteistöä totutusta poikkeavasti. ${ }^{8}$

Vaikka Strik viljeleekin runsaasti länsimaisen taidemusiikin käsitteistöä ilahijoista puhuessaan, hän pitää islamilaista laulantaa ja länsimaista taidemusiikkia toistensa vastakohtina. Strikin musiikillisessa maailmankuvassa on runsaasti myyttisiä elementtejä.

\section{Ilahija-myytti}

Roland Barthesin (1985, 112-114) mukaan modernit myytit ovat katkelmallisia. Ne esiintyvät sanontoina ja stereotyyppisinä ilmauksina niin puheessa ja kirjoituksissa kuin myös valokuvissa, elokuvissa tai mainoksissa. Myyttisten ilmaisujen kieli on merkitykseltään kaksinaista metakieltä, joka ilmaisee normaalin viestin lisäksi jonkin myyttisen uskomuksen tai arvostuksen. Usein myyttinen metakieli nousee ensisijaista viestiä tärkeämmäksi ja tuo ilmaukseen uuden, ideologioihin tai oppijärjestelmiin liittyvän sisällön. Tämä myyttinen alue saattaa olla epämääräinen, vaikeasti määriteltävä.

Strikin islamilaisesta laulannasta ja länsimaisesta taidemusiikista esittämät ajatukset näyttävät tukevan Claude Lévi-Straussin teoriaa, jonka mukaan myytit ovat aina sidoksissa vastakohtapareihin. Näiden binaaristen oppositioiden toinen puolisko on myöteinen ja toinen kielteinen. (Ks. Lévi-Strauss 1969, 223-224).

Strik vertaa luonnon ja teknologian suhdetta ilahijan ja taidesävelmän suhteeseen. Hänen mielestään metsässä on täysin rauhallista silloinkin kun siellä kuuluu tuulen tai eläinten ääniä. Ne eivät häiritse rauhaa, koska metsän rytmi hallitsee niitä. Sen sijaan metsän rytmille vieras moottorin ääni rikkoo rauhan. (Strik 1988, 4).

Zikirin esma-osan muuttumaton, harmoninen hengitysrytmi muistuttaa metsän rytmiä. Se on kaikenkattava, yhtenäinen ja jumalallinen. Voimakkaat hengitysäänet säestävät ilahijaa orkesterin lailla. Varsinaiset soittimet helpottavat rytmin säilymistä muuttumattomana. Islamilaisen laulannan päämääränä onkin jumalallisen, harmonisen rytmin saavuttaminen, kun länsimainen taidemusiikki tavoittelee aistinautintoa. (Ibid.).

8) Haastattelutilanne voi vaikuttaa merkittävästi informantin vastauksiin. Strik on saattanut tuntea asiantuntijaroolinsa vaativan musiikkitermien ylenmääräistä ja ulkopuolisesta epäloogiselta näyttävää käyttöä tilanteessa, jossa yleisönä oli neljä muuta dervissiä. (Vrt. Benson-Hughes 1983, 25). 
Ilahijan laatijaa ei useinkaan tunneta, koska tämä ei ole halunnut itselleen henkilökohtaista tunnustusta. Taidemusiikissa säveltäjä nimenomaan tavoittelee mainetta. Ilahijaa esitettäessä kuulijat pyritään aktivoimaan, kun taas taidemusiikin esitystilanteessa yleisö on passiivinen. Tekijassa voi 'opettaa' Strikin kertoman mukaan kuka tahansa henkilö, jolla on hyvä ääni ja joka tuntee halua 'opettaa'. Toisaalta 'opettaminen' vaatii harjoittelua. Sävelmät ovat yleensä helppoja, joten maallikot omaksuvat ne vaikeuksitta. Ilahijoiden 'opettamiseen' voi osallistua kuka tahansa, koska esitys ei ole ammatillinen eikä kaupallinen. Jokainen voi omaksua ilahijan, mutta taidemusiikissa tarvitaan musiikillista koulutusta, johon tavallisella ihmisellä ei ole aikaa. Ilahijat vaativat kuulijan omakohtaista kiinnostusta ja ne tarjoavat deduktiivisen metodin uskonnollisen tietouden ja kasvatuksen hankkimiseen. Tämä tarkoittaa sitä, ettei kuulija tyydy vain kuuntelemaan, vaan hän kiinnostuu uskonnon järjestelmällisestä opiskelusta. (Ibid.; Y 9750; Strik 1987, 152).

Ilahija-runon kirjoittanut dervissi on Strikin mukaan aina antanut tekstilleen myös sävelmän. Muussa musiikissa sanoittajana ja säveltäjänä toimivat eri henkilöt. Kun sama henkilö kirjoittaa tekstin ja laatii sille melodian, inspiraation määrä vähenee. Näin sävelmä ja teksti muodostavat kokonaisuuden, joka erottaa ilahijat muista lauluista. Jos 'opettaja' ja kuulija ovat riittävän sensitiivisiä, ilahija saa heissä aikaan samoja uskonnollisia tuntoja kuin ilahijan laatijalla oli ollut. Sitä vastoin taidemusiikkiin perehtyminen vaatii usein joutilaisuutta ja haaveilua. Se johtaa etenkin nuoret taiteelliseen kuvitteluun, musiikista päihtymiseen. (Y 9750; Strik 1987, 151; ibid. 1988, 5).

Ilahijat ovat yhteisöä ja amatöörejä varten. Ne aktivoivat kuulijoita ja ovat spontaaneja. Taidemusiikki on ammattilaisia varten ja kaupallista. Kielteisistä puolistaan huolimatta taidemusiikki ei ole islamin mukaan kiellettyä. Se on silti rajoitettua. (Strik 1988, 5).

Strik väittää kaikkien ilahijoiden olevan duuriasteikossa. Poikkeuksen muodostavat valituslaulut eli mersijat, jotka ovat mollissa. Ilahijoissa käsitellään usein kuoleman jälkeistä elämää. Strikin mielestä ilahijat tuovat esiin Koraanin myönteisen asenteen kuolemaa kohtaan niin tekstin kuin sävelmän avulla. Ilahijan duuriluonne ja muiden uskontojen, erityisesti kristinuskon, mollimelodiat ovat vastakohtia. Koska kristillinen käsitys kuolemasta on kielteinen, messut ja requiemit ovat surullisia. (Strik 1987, 151; Y 9749). 
Strikin näkemyksistä löytyy vastakohtapareja, jotka ryhmittyvät sakraalin ja profaanin oppositioiden mukaan. Sakraali edustaa myönteistä, profaani kielteistä.

\author{
sakraali (myönteinen) \\ Jumala \\ luonto \\ järjestys \\ ilahija \\ uskonnollinen tieto \\ kokonaisvaltaisuus \\ emotionaalisuus \\ pyyteettömyys \\ spontaanius \\ aktiivisuus \\ amatöörius \\ kaikkia varten
}

\section{profaani (kielteinen)}

ihminen
teknologia
epäjärjestys
länsimainen taidemusiikki
hedonismi
osittuneisuus
teknisyys
maineen tavoittelu
ennakolta järjestely
passiivisuus
ammattilaisuus
eliittiä varten

Vastakohtapareissa tulee esille vanha islamilainen käytäntö erottaa toisistaan musiikin opintoja vaativa ammattilaisille kuuluva profaani laulaminen (ghinâ) ja sakraali laulanta (taghbîr). Käsitys siitä, että ilahijaa kuuntelemalla saavutetaan haltioituminen ja uskonnollista tietoa, on selvästi sufilainen piirre.

Strikin käsitykset ilahijoista muistuttavat luterilaiseen virsilauluun liitettyjä näkemyksiä. Koska musiikki oli reformaation kannattajille keino levittää evankeliumia ja voimistaa protestanttien uskonnollista tunnetta, Luther piti virsien kansankielisiä sanojen ja helposti omaksuttavan sävelmän muodostamaa kokonaisuutta tärkeänä (Söhngen 1983, 14).

Sakraalin ilahijan ja profaanin länsimaisen taidemusiikin vastakohtaparille on löydettävissä välimuoto, koska sama melodia saatetaan tuntea sekä ilahijana että profaanina lauluna. Strik $(1987,152)$ kirjoittaa monien urbaanien sevdalinka-rakkauslaulujen sävelmien olevan peräisin turkkilaisista ilaheista. Hän mainitsee ilahijan "Džudbi-lutfik" ja sevdalinkan "Kad ja podjoh na Bendbašu", ilahijan "Ja ilahi..." ja sevdalinkan 
"Uzeh djugum..." sekä ilahijan "Ey çerhidun..." ja sevdalinkan "Alija se do jezera krade". Kaiken kaikkiaan Strik on havainnut parikymmentä vastaavaa lainautumista, mutta ei ole nuotintanut niitä.

Länsimainen taidemusiikki on vaikuttanut sevdalinkoihin. Tämän voi kuulla etenkin Sarajevon radion orkestereiden esitysten soinnutuksessa ja virtuoosisissa soitinosuuksissa. Sovitus ja soitinnus saattavat noudattaa länsimaisia malleja. (Ks. esim. Himzo Polovina, Narodne pjesme iz Bosne i Hercegovine).

A. J. Greimasin (1980, 206-207) kehittämässä myyttisessä aktanttimallissa myytin peruselementit on luokiteltu subjektiin, objektiin, lähettäjään, vastaanottajaan, auttajaan ja vastustajaan. Aktanttien eli toimijoiden suhteet perustuvat subjektin objektiin kohdistamaan tahtomiseen. Objekti on samalla lähettäjän ja vastaanottajan välisen kommunikaation objekti. Strikin esittämässä ilahija-myytissä subjektina ovat dervissit ja objektina on Jumala, jota mystikot pyrkivät lähestymään. Lähettäjänä on sufismi ja vastaanottajana ihmiskunta, varsinkin muslimit. Auttajan rooliin jää ilahija, jonka luonnollinen vastustaja on länsimainen taidemusiikki.

Kuvio 1. Seid Strikin kertoman ilahija-myytin aktanttimalli.

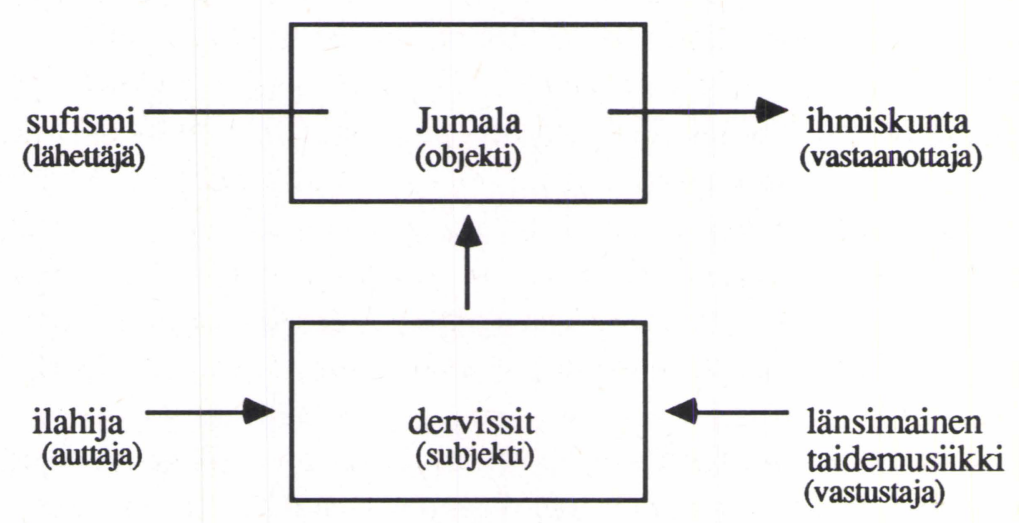

Ilahijalla ei näytä olevan sufismissa paljonkaan itseisarvoa, vaan se on väline Jumalaa koskevan metafyysisen tiedon saavuttamiseksi. Strik $(1987,152)$ pitää ilahijan välinearvoa niin suurena, että laulannan merkitystä tulisi painottaa sekä sufismin levittämisessä että sen opettamisessa. 
Strik pahoittelee artikkelissaan, että ilahijoiden laillisuudesta huolimatta islamilaiset oppineet ja korkeissa uskonnollisissa viroissa toimivat henkilöt suhtautuvat niihin kielteisesti. Kuitenkin ilahijat kuuluvat hänen mielestään sharî'a-lain al-nasut -luokkaan eli hyödyllisiin ja luvallisiin luomuksiin, koska ne ovat opettavia ja sivistäviä. Hänen ohjelmajulistuksensa mukaan ilahijoiden asema parantuisi, jos laulut kerättäisiin talteen ja luokiteltaisiin. Sävelmät tulisi tallentaa ja mahdollisesti nuotintaa. Myös kirjallisuus- ja musiikkitieteellinen ilahija-tutkimus on tärkeää. Nuoret muslimiteologit olisi saatava käsittelemään ilahijoita kirjoituksissaan, joilloin ne saisivat entistä merkittävämmän roolin uskonelämässä. (Strik 1987, 149; 152).

Voi tuntua paradoksaaliselta, että mystikko Strik haluaa vahvistaa sakraalin laulannan asemaa länsimaisen rationaalisen tieteen avulla. Nähtävästi hän on omaksunut ainakin joitain länsimaisen tieteenihanteen piirteitä opiskellessaan kemianopettajaksi. Toisaalta modernille islamille on ominaista länsimaisen tieteen ja tekniikan hyödyntäminen islaminopin päämäärien saavuttamiseksi.

Strik on kiinnostunut ilahijoiden varhaisista nuotinnosyrityksistä. Hän kertoo turkkilaisen mevlevî-Seikki Galib Deden nuotintaneen ilahijoita omalla erikoissysteemillään jo melko varhain. Strik siis pitää länsimaista nuotinnosjärjestelmää normina, jonka rinnalla Galib Deden nuottikirjoitus on erikoissysteemi. Hän lisää toisen mevlevî-šeikin, Mustafa Itrî Çelebin, nuotintaneen ilahijoita eurooppalaisella notaatiolla 1800-luvulla. Nezih Uselin kertoman mukaan Galib Dede kuoli vuonna 1844, eikä hän kehittänyt omaa notaatiojärjestelmää. Kudsi Ergunerin mielestä Strik tarkoittaa Mustafa Itrî Çelebistä puhuessaan mevlevîsäveltäjä Buhûrîzade Mustafa Itrîä (1640-1712). On varmaa, ettei Itrî käyttänyt eurooppalaista notaatiota. (Strik 1987, 151; Usel 1990; Erguner 1990).

Länsimainen musiikillinen maailmankuva on vaikuttanut Strikin käsitykseen uusien ilahijoiden oppimisprosessista. Hän sanoo, että ilahijoiden melodiat ja tekstit opetellaan kotona ja tekijassa joko korvakuulolta tai turkkilaisista nuottijulkaisuista. Strikin mielestä sävelmän oppii helpoiten soittamalla sitä pianolla tarpeeksi monta kertaa. Sävelmän oppinut henkilö opettaa sen toisille. Strik huomauttaa soittamisen vaativan kykyä lukea nuotteja, mikä on harvinainen taito Sarajevon dervissien keskuudessa. Hänen mielestään turkkilaista sabâ-makamia 
seuraava melodia voidaan soittaa pianolla. (Y 9750). Tämä johtuu siitä, että hän pitää puolisävelaskelta ja mikrointervallia samana asiana.

Vaikuttaa siltä, ettei Strik luota mystikkoveljeskunnissa aiemmin toimineeseen ilahija-sävelmien suulliseen välitysmekanismiin. Tämä voi olla merkki sufilaisen perinteen heikentymisestä. Toisaalta Strikin halu nuotinnuttaa ilahijoita voi juontaa juurensa länsimaisessa taidemusiikissa 1700-luvun lopulta ja 1900-luvulle vallinneesta sävellyksen käsitteestä, joka vaati tarkkaa nuottikuvaa. Islamilaisella kulttuurialueella tämä ajatus oli vieras ennen länsimaisen vaikutuksen alkua. Turkissa nuottikirjoituksen käyttöönotto 1800-luvulla merkitsi uudenlaisen esityskäytännön syntyä. Aiemmin taidemusiikki oli välittynyt ainoastaan suullisesti. Nuotinnettuja sävellyksiä ei mielletty enää siinä määrin vapaasti muunneltaviksi melodiarungoiksi kuin ennen. (Reinhard 1973, 25-26).

\section{Aitouden ongelma}

Strikin mielestä ilahijoita ei synny eivätkä ne välity enää samaan tapaan kuin Bosnian sufismin ollessa vielä vahva perinne. Nykyiset ilahijarunoilijat kykenevät enää vain jäljittelemään edeltäjiään, mikä on tekijänoikeuden loukkaamista. Nämä pahansuovat henkilöt haluavat näyttää runoilijantaitonsa lainaamalla säkeitä vanhoista runoista, muuttamalla säkeiden järjestystä toiseksi, hylkäämällä turkkilaisuuksia tai kokonaisia säkeistöjä, muuttamalla ilahijan päättävän sahbejt-säkeistön sekä vaihtamalla turkinkielisten sanojen merkityksiä. Strikin mielestä näin muokattu runo menettää autenttisuutensa ja syntyajankohtansa kielelliset erityispiirteet. (Strik 1987, 150). Strikin mielestä runolla on siis yksi oikea alkumuoto. Hän hyväksyy uuden sävelmän laatimisen vanhaan runoon. Tämä johtuu kaiketi siitä, että sanat ovat melodiaa tärkeämmät.

Nezih Uzel (1990) tunnisti Sarajevon mevlevija-veljeskunnan kokoontumisissa lauletun ilahijan "Ya Mevlâna" sadiya-veljeskunnan ilahijaksi "Serveri ser bülendimiz". Sarajevolaisessa versiossa sadiyan perustajan Sa'd-al-Din Jibawin nimi on korvattu mevlevîn perustajan Mevlâna Celâleddin al-Rûmin nimellä (ks. nuottiesimerkki 4). Samalla alkuperäisen ilâhin tasajakoisuuteen on ilmaantunut kaksi viisi-iskuista tahtia..$^{9}$ (Y 9750; Uzel 1990). Balkanilla ei ole sadiya-dervissejä, joten toisen veljeskunnan hyväksi koetun ilahijan ottaminen käyttöön hieman

9) Uzel ja Erguner esittävät tämän ilahijan sadiya-version levyllä Turquie: Musique Soufi. 
muunnettuna on ymmärrettävää.

Nuottiesimerkki 4. Mevlevija-zikirin jälkeen 'opetettu' ilahija "Ya Mevlâna" (Y 9735).

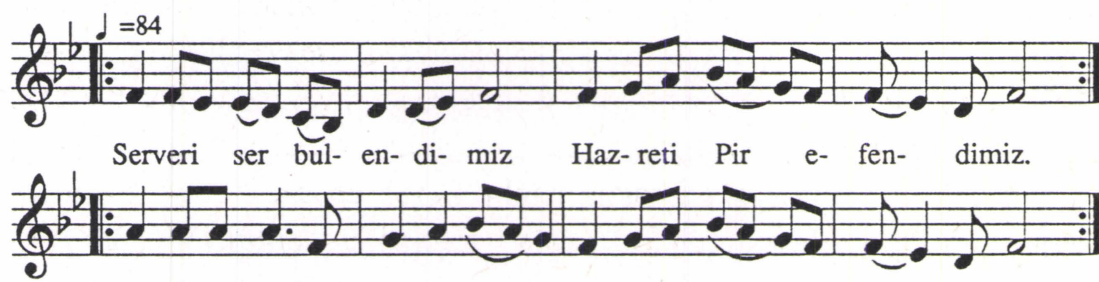

Şah idi şah le- vendi- miz Haz-reti Pir e- fen- dimiz.
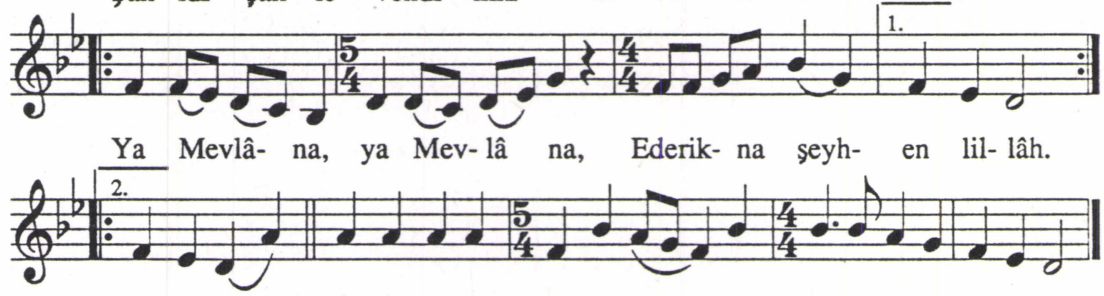

en lillâh Allah Allah Ya Allah Hak Lâ ilâ- he ill'Allâh.

Itse asiassa uusien runojen laatiminen vanhojen pohjalta kuuluu arabialaiseen kulttuuriin. Niinpä al-Bușîrîn "al-Berdun" mallia seuraten on kirjoitettu lukemattomia sakraaleja runoja (ks. Touma 1989, 200-201). Strik ei näytä asiantuntijuudestaan huolimatta tuntevan arabialais-islamilaisen kirjallisuuden periaatteita; hän puolustaa runoluomuksen ainutkertaisuutta ja runoilijan oikeuksia tuotteeseensa, mikä saattaa olla länsimaisen individualismin vaikutusta.

$* * *$

Bosnialainen kulttuuri on ollut pitkään jatkuvassa akkulturaatiotilassa: uusi innovaatiovyöry on saavuttanut maakunnan ennen kuin vastaanottajat ovat kyenneet sopeuttamaan aiemmin saapuneet innovaatiot. Islamilaisesta sakraalista laulannasta käytettyjen käsitteiden moninainen alkuperä kuvastaa Bosnia-Hertsegovinan muslimien kulttuuris-maantieteellistä asemaa Lähi-idän ja Keski-Euroopan kulttuurikeskusten välissä. Sarajevon dervissien musiikkikulttuuri on varsin tyypillinen marginaalikulttuuri. Siinä yhdistyy Bosnian maaseudun, Lähi-idän sekä Keski-Eu- 
roopan säätyläisten musiikkikulttuurien piirteitä. Seid Strikin musiikillinen maailmankuva sisältää aineksia niistä kaikista.

Tekija-paikoissa käyvät pyrkivät kuvaamaan islamilaista musiikkiperinnettä esi-islamilaisen slaavilaisperäisen, arabialais-turkkilaisen sekä alueelle viimeksi tulleen länsimaisen taidemusiikin käsitteistöjen avulla. Moskeijan rituaaleihin liittyvistä laulantalajeista ei kuitenkaan käytetä länsimaisia käsitteitä. Rukouskutsu, koraaniresitaatio sekä tekbir- ja salavat-kaavat koetaan niin läheisesti islamiin kuuluviksi ilmiöiksi, että niistä puhutaan pelkästään kaikille yhteisen arabialais-turkkilaisen peruskäsitteistön avulla. Sen sijaan moskeijan ulkopuolisista laulantalajeista - erilaisista ilahijoista ja gazelista - on mahdollista käyttää sekä slaavilaisperäisiä, arabialais-turkkilaisia että länsimaisia käsitteitä. Ilahijoista ja gazeleista vallitsee monenlaisia spontaaneja käsityksiä.

\section{Lähteet}

Painetut lähteet ja käsikirjoitukset

Anonym

1989 "Qașîda". Encyclopaedia Britannica. Micropaedia

vol. 9, 352. Chicago.

Barthes, Roland

1985 Mythologies. Aylesbury.

Benson, Douglas-Hughes, John A.

1983 The Perspective of Ethnomethodology. London-New

York.

Burckhardt, Titus

1960 Fes, Stadt des Islam. Olten-Freiburg.

Ćehajić, Džemal

1986, Derviški redovi u jugoslovenskim zemljama. Orientalni institut u Sarajevu. Posebna izdanja XIV. Sarajevo.

Cooke, Deryck

1959 The Language of Music. London.

Farmer, Henry George

1957 "The Music of Islam". The New Oxford History of Music 421-477. London.

Filipović, Muhamed - Hadžidedić, Nedžad

1983 "Nations and Nationalities of Bosnia and Hercegovina". 
The Socialist Republic of Bosnia and Hercegovina. Enci-

klopedija Jugoslavije, 120-127. Zagreb.

Greimas, A.J.

1980 Strukturaalista semantiikkaa. Tampere.

Hadžibajrić, Fejzulah

1979 "Tesawuf, tarikat i tekije". Islamska misao.

Maj/Džumadel-uhra 1979/1399. Broj 6. Godina I, 18-20.

Hadžisalihović, Jasna

1973 "Bosanski mekam". 18. Zbornik kongresa jugoslovanskih

folkloristov; Bovec 1971. ured. Zmaga Kumar, 248-250.

Ljubljana.

Huković, Dr Muhamed

1986 Alhamijado književnost i njeni stvaraoci. Sarajevo.

Kalendar

Kalendar održavanja zikira. Sarajevo 8.1.1981. Painamaton.

Karttunen, Sanna

1990 Musiikillisen maailmankuvan rakenne ja tyypit musiikki kirjastonhoitajilla. Käsikirjoitus.

Koskoff, Ellen

1982 "The Music-Network: A Model for the Organization of

Music Concepts." Ethnomusicology. Volume XXVI Sept.

1982:3.

Lévi-Strauss, Claude

1969 Structural Anthropology. Aylesbury.

Lockwood, William G.

1984 "Bosnians". Muslim Peoples. A World Ethnographic

Survey. ed. Richard V. Weekes, 172-177. 2nd ed.

Westport.

Manuel, Peter

1989 "A Historical Survey of the Urdu Gazal-Song in India." Asian Music. Volume XX, Number 1. Fall/Winter 198889, 93-113.

Markotić, Ante

1983 "Social Basis. Population". The Socialist Republic of Bosnia and Hercegovina. Enciklopedija Jugoslavije, 2838. Zagreb.

Nasr, Seyyed Hossein

1976 "Islam and Music. The Views of Rûzbahân Baqît, the 
Neubauer, Eckhard

Patron Saint of Shîrâz". Studies in Comparative Religion Vol. 10 No. 1, Winter 1976, 36-45.

1980 "Islamic Religious Music". The New Grove Dictionary of Music and Musicians vol. 9, 342-349. London.

Pennanen, Risto Pekka

1990a Sarajevon islamilaiset mystikkoveljeskunnat ja niiden laulanta. Kansanperinteen, erityisesti kansanmusiikin pro gradu -tutkielma. Tampereen yliopisto.

1990b "Kiellettyä, rajattua, sallittua - islam ja musiikki". Marhaba 1990, 40-45.

Petrović, Ankica

1989 "Paradoxes of Muslim Music in Boznia [sic] and Herzegovina". Asian Music. Fall/Winter 1988/89, 128-147.

Reinhard, Kurt

1973 "Die Türkei im 19. Jahrhundert". Musikkulturen Asiens, Afrikas und Ozeaniens im 19. Jahrhundert. Herausgegeben von Robert Günther. Studien zur Musikgeschichte des 19. Jahrhundert. Band 31. Regensburg.

Reinhard, Kurt -Reinhard, Ursula

1984 Musik der Türkei. Band 1: Die Kunstmusik. Taschenbücher zur Musikwissenschaft 95. Wilhelmshaven.

Rithman, Cvjetko

1951 "Čičak Janja, narodni pjevač sa Kupresa". Bilten. Institut za proučavanje folklora u Sarajevu I, 33-63. Sarajevo.

Robson, James

1938 Tracts on Listening to Music. London.

Signell, Carl L.

1977 Makam. Modal Practice in Turkish Art Music. Asian

Music Publications Series D, number 4. Washington. Škaljic, Abdulah

1985 Turcismi u spskohrvatskom jeziku. Peto izdanje. Sarajevo. Spaić, Jasna

1989 "Islamsko obredno pjevanje po bosanskom mekamu". Akademija nauka i umjetnosti Bosne i Hercegovine. Nauče komunikacije XXIII. Prvi javni sastanak. Medjuakademijskog koordinacionog odbora za ispitivanje tradicionalne narodne religiozne obredne muzike $\mathrm{u}$ Jugoslaviji, 43-52. Sarajevo. 
Strik, Seid

1987 "Ilahije". Šebi-arus 87, 149-152

1988 Tekijske melodije. Painamaton.

Söhngen, Oskar

1983 "Music and Theology: A Systematic Approach". Sacred

Sound. Music in Religious Thought and Practice. ed.

Joyce Irwin, 1-19. Journal of the American Academy of

Religion Thematic Studies 50/1. Chico.

Touma, Habib Hassan

1989 Die Musik der Araber. Taschenbücher zur Musikwissenschaft 37. Erweiterte Neuausgabe. Wilhelmshaven.

Trimingham, J. Spencer

1971 The Sufi Orders of Islam. London.

Kenttätyönauhat

Tampereen yliopiston Kansanperinteen laitoksen yleiskokoelmat

Y $9734 \quad$ Kadirija-zikir Hadži-Sinanova -tekijassa 4.2.1988.

Y 9735 Mevlevija-zikir Mlini-tekijassa 5.2.1988.

Y $9739 \quad$ Nakšibendija-zikir Milini-tekijassa 12.2.1988.

Y $9740 \quad$ Nakšibendija-zikir Milini-tekijassa 12.2.1988.

Y 9742 Rifaija-zikir Nimar Sinanova -moskeijassa 16.2.1988.

Y 9747 Kadirija-zikir Hadži-Sinanova -tekijassa 25.2.1988.

Y 9748 Kadirija-zikir Hadži-Sinanova -tekijassa 25.2.1988.

Y 9749 Nakšibendija-zikir Mlini-tekijassa 26.2.1988.

Y 9750 Nakšibendija-zikir Mlini-tekijassa 26.2.1988.

Risto Pekka Pennasen kokoelmat

Uzel 1990

Muusikko Nezih Uzelin haastattelu Helsingissä 12.6.1990.

Erguner 1990

Muusikko Kudsi Ergunerin haastattelu Helsingissä 12.6. 1990. 
Kaupalliset äänitteet

Amanédhes. Margo 8222. 1981.

Himzo Polovina, Narodne pjesme iz Bosne i Hercegovine. Jugoton LPY-S-60957.

Ilahije $i$ kaside. U povodu 450 godina Gazi Husrevbegove medrese. Jugoton UCAY 646. 1988.

Iran 5 \& 6: Baloutchistan. Musiques d'extase et de guérison. Ocora 558565/66. 1981.

Ja'sin. Uči: Profesor Cerić Mustafa. Odbor za gradnju džamije u Zagrebu. Jugoton UCAY-222. 1980.

Kur'an - ezan - salaat - ilahije. Islamska Zajednica. Odbor za gradnju džamije u Zagrebu. Jugoton UCAY 223. 1980.

Rembétiki istória 1925-55:1. Epimeleia Kosta Hadzidouli. EMI Regal 14 C 034-70364. 1974.

Turquie: Musique Soufi. Ocora C559017. 1987. 